\title{
Good Morning to Good Night Greeting Classification Using Mel Frequency Cepstral Coefficient (MFCC) Feature Extraction and Frame Feature Selection
}

Klasifikasi Ucapan Selamat Pagi Sampai Selamat Malam Menggunakan Ekstraksi Ciri Mel Frequency Cepstral Coefficient (MFCC) dan Pemilihan Fitur Frame

\section{Heriyanto}

Informatika, Universitas Pembangunan Nasional Veteran Yogyakarta, Indonesia

heriyanto@upnyk.ac.id

*: Penulis korenspondensi (corresponding author)

\section{Informasi Artikel}

Received: 30 December 2020

Revised: 25 January 2021

Accepted: 17 February 2021

Published: 28 February 2021
Keywords: extraction of features, features, frames, cepstral coefficient, linear

Kata kunci: ekstraksi ciri, fitur, frame, cepstral coefficient, linier

\author{
Abstract \\ Purpose: \\ Select the right features on the frame for good accuracy \\ Design/methodology/approach: \\ Extraction of Mel Frequency Cepstral Coefficient (MFCC) \\ Features and Selection of Dominant Weight Normalized \\ (DWN) Features \\ Findings/result: \\ The accuracy results show that the MFCC method with the \\ 9 th frame selection has a higher accuracy rate of $85 \%$ \\ compared to other frames. \\ Originality/value/state of the art: \\ Selection of the appropriate features on the frame.
}

\section{Abstrak}

\section{Tujuan:}

Pemilihan fitur yang tepat pada frame untuk mendapatakan akurasi yang baik.

Perancangan/metode/pendekatan:

Ekstraksi Ciri Mel Frequency Cepstral Coefficient (MFCC) dan Pemilihan Fitur Normalisasi Bobot Dominan (NBD).

Hasil:

Hasil akurasi didapat bahwa metode MFCC dengan pemilihan frame yang ke-9 mempunyai tingkat akurasi yang lebih tinggi sebesar $85 \%$ dibandingkan dengan frame yang lain.

Keaslian/ state of the art:

Pemilihan Fitur yang tepat pada frame. 


\section{Pendahuluan}

Selamat pagi, selamat siang, selamat sore dan selamat malam ucapan salam dalam bahasa Indonesia sehari-hari dan klasifikasi ucapan selamat tersebut dilakukan dengan pemilihan fitur frame. Pemilihan fitur frame sangat diperlukan dalam pengenalan ucapan, karena hanya pemilihan fitur yang tepat sangat berpengaruh terhadap akurasi dan tidak semua fitur terutama semua fitur frame dipakai untuk akurasi. Metode ekstraksi ciri umum dan banyak digunakan diantaranya menggunakan Mel Frequency Cepstral Coefficient (MFCC) dan Linier Predicted Code (LPC).

\subsection{Metode ekstraksi ciri}

Metode pengenalan suara yang menggunakan ekstraksi ciri sangatlah penting karena hasil dari ekstraksi ciri tersebut yang berupa fitur sangat berpengaruh terhadap hasil kecocokan dan pengecekan pengenalan pola. Penelitian yang menggunakan metode ekstraksi ciri di antaranya Mel Frequency Ceptrum Coefficients (MFCC) dan Linear Predictive Code (LPC) [1]. Kedua metode tersebut mempunyai kelemahan dan kelebihan di dalam ekstraksi ciri yang menghasilkan fitur.

MFCC memiliki kelemahan di antaranya terletak pada frekuensi rendah, kebisingan lingkungan, kepekaan, pola suara yang hampir mirip dan pengklasifikasian (Syafria dkk., 2014). Sedangkan, MFCC memiliki kelebihan di antaranya mampu menangkap karakterisik suara yang penting dalam pengenalan, menangkap informasi yang penting dalam suara, menghasilkan data seminimal mungkin tanpa menghilangkan informasi dan mereplikasi suara pendengaran manusia [3]. Selain itu, ekstraksi ciri menggunakan MFCC banyak digunakan untuk pengenalan suara dikarenakan lebih presisi dalam berbagai kondisi [4].

Metode ekstraksi ciri yang menggunakan Linear Predictive Code (LPC) mempunyai kelemahan di antaranya derau atau noise, frekuensi ucapan yang berubah-ubah dan pengklasifikasian (Irmawan dkk., 2014). Metode ini mempunyai kelebihan berupa autokorelasi [1], [6]. Penelitian ekstraksi ciri suara baik yang menggunakan MFCC dan LPC mempunyai kelemahan yang sama di antaranya derau atau noise, frekuensi ucapan yang hampir mirip, frekuensi yang sering berubah-ubah dan pengklasifikasian. Kelemahan kedua metode tersebut juga diungkapkan oleh Abriyono dan Harjoko [1] bahwa ekstraksi ciri yang menggunakan MFCC dan LPC tidak cocok untuk mengenali suara jumlah yang sangat besar sehingga diperlukan pengklasifikasian. Berdasarkan kelemahan dan kelebihan dari kedua metode tersebut baik ekstraksi ciri yang menggunakan MFCC dan maupun LPC, maka peneliti lebih memilih ekstraksi ciri yang menggunakan MFCC dikarenakan dari tingkat keakurasian lebih baik dibandingkan dengan LPC. Ekstraksi ciri MFCC di antara 58-75\%. Selain itu, metode LPC menurut Widodo dkk., [9] lebih cocok untuk komputasi yang bersifa linear, sedangkan suara manusia pada dasarnya bersifat nonlinier.

Penelitian pengenalan suara yang menggunakan MFCC telah banyak dilakukan dalam semua bidang termasuk diterapkan dalam bidang bahasa. Penelitian pengenalan suara dalam bidang bahasa Arab oleh Chamidy [4] bahwa ekstraksi Mel Frequency Cepstral Coeffisients (MFCC) berupa fitur untuk mendapatkan nilai kesesuaian pada penutur Indonesia terhadap penutur aslinya diklasifikasi menggunakan Hidden Markov Model (HMM). MFCC diterapkan dalam bidang bahasa yang lain di antaranya bahasa Indonesia dengan mengidentifikasi sinyal ucapan menjadi kosakata yang menghasilkan Phonem and Syllable Models dan segmentasi [10]. 
Penelitian serupa dilakukan oleh Suyanto dan Putra [11] menggunakan Mel Frequency Ceptral Coefficient (MFCC) dan Hidden Markov Model (HMM) yang mampu mengenali segmentasi fonem dalam bahasa Indonesia. Penelitian sejenis tentang fonem juga dilakukan oleh Cahyarini dkk., [12] yang mampu mengidentifikasi ucapan jeda antara fonem.

Penelitian lain yang terkait dengan bahasa tentang pengenalan huruf hijaiyyah oleh Bethaningtyas [13] menggunakan MFCC dengan membandingkan penggunaan 3, 6, 9 dan 12 channel dari model data latih dan nilai deviasi. Penelitian lain terkait huruf hijaiyah oleh Heriyanto [14] menggunakan metode evarage energy dan deviasi wave sebagai pembanding. Sedangkan penelitian lain terkait fonem huruf hijaiyyah oleh Subali dkk., [15] menggunakan metode LPC dan DTW menghasilkan frekuensi formant pembicara dalam pengucapan dan DTW mempunyai kelebihan berupa autokorelasi.

Penelitian MFCC yang lain dengan cara memodifikasi dilakukan oleh [16] pada bagian windowing. Penelitian lain juga dengan memodifikasi MFCC menghasilkan analisis acoustic signal dengan tahapan preemphasis, frame blocking, hamming windowing, Fast Fourier Transform, Mel Filterbank, Discrete Cosine Transform (DCT), Delta energy dan delta spectrum.

\section{Metode/Perancangan}

Penelitian pengenalan suara menggunakan cara yang berbeda-beda menghasilkan keluaran yang berbeda-beda pula di antaranya dengan cara jaringan syaraf tiruan atau neural network [18], Hidden Markov Model (HMM) [4], pengenalan suara dengan Dynamic Time Wrapping (DTW) [19]. Pengenalan suara dengan metode DTW dilakukan untuk menghitung jarak antara dua data time series. Metode ini mempunyai keunggulan mampu menghitung jarak antara dua vektor data dengan panjang yang berbeda atau mengetahui nilai jarak terkecil pencocokan antara suara pembicara pemula dan pembicara ahli. DTW menurut Miftahuddin dan Hakim [19] merupakan algoritma sebagai non-linear sequence alignment, digunakan untuk mengukur kemiripan suatu pola dalam kawasan rentetan data bervariasi terhadap waktu dan lebih realiastis.

DTW mempunyai kelemahan dari segi akurasi yaitu dengan hasil yang sangat bervariasi Novianto dan Yuliantari [21] dan masih menyamai tingkat akurasi HMM [4]. Sedangkan penggunaan metode HMM menurut Suyanto dan Putra [11] mempunyai kelemahan dari segi kurang tahan atau robust. Metode pengenalan suara yang lain menggunakan Neural Network (NN) mempunyai kelebihan pada sistem pembelajaran, akuisisi pengetahuan, klasifikasi dan generalisasi suatu pola [18]. NN menurut Martyna dan Sudaryanto [22] mempunyai kelemahan pada proses training memerlukan waktu yang cukup lama dengan jumlah data yang besar. Pernyataan yang sama oleh Aibinu dkk., [23] untuk mengidentifikasi ucapan angka satu sampai dengan angka sembilan mempunyai kendala pada saat proses training dengan data yang sangat besar membutuhkan waktu proses yang sangat lama.

Metode MFCC diperkenalkan pertama kali oleh Davis dan Mermelstein sekitar tahun 1980. MFCC salah satu metode yang cukup baik dalam pengenalan suara dalam bidang speech recognition [24]. MFCC merupakan ekstraksi ciri yang paling banyak digunakan dalam bidang speaker recognition dan speech recognition. MFCC merupakan ekstraksi ciri yang menghasilkan fitur atau ciri yang merupakan pembeda satu dengan yang lain berupa parameter 
cepstral coefficient [1]. Ekstraksi ciri Mel Frequency Cepstral Coefficient (MFCC) mengubah gelombang suara menjadi beberapa tipe parameter seperti cepstral coefficient yang mempresentasikan audio file [4]. Selain itu MFCC menghasilkan fitur vektor yang mengonversi sinyal suara menjadi beberapa vektor untuk pengenalan fitur suara (Putra dkk., 2011).

MFCC mempunyai tahapan yaitu pre-emphasis, frame blocking, windowing, Fast Fourier Transform (FFT), Mel Frequency Wrapping (MFW), Discrete Cosinus Transform (DCT) dan cepstral liftering yang menghasilkan parameter sebagai fitur yaitu frame dan cepstral coefficient.

\subsection{Pre-emphasis}

Pre-emphasis menurut Chitode [25] melakukan penekanan pada komponen frekuensi tinggi, menyelaraskan pada frekuensi rendah dan frekuensi tinggi. Pre-emphasis menurut Tokunbo Ogunfunmi [26] mengurangi kebisingan untuk memperbaiki Signal to Noise Rasio (SNR) dan mengurangi suara yang tidak diinginkan. Pre-emphasis merupakan pemrosesan signal sederhana yang pada dasarnya adalah filter linear dan masih dalam ranah waktu [27].

Pre-emphasis merupakan tahap awal dalam proses MFCC. Tahap ini, dilakukan karena sinyal sering sekali mengalami gangguan noise, sehingga diperlukan untuk mengurangi noise atau derau. Pre-emphasis merupakan cara yang sangat sederhana dalam mengurangi noise. Preemphasis mempunyai tujuan agar level base band pada bagian frekuensi tinggi masih memiliki kualitas sinyal yang baik. Proses pre-emphasis menurut Proakis dan Manolakis [28] dengan nilai $\alpha$ di antara 0 sampai 1 atau di antara $0,9 \leq \alpha \leq 1,0$ menggunakan persamaan (1)

$$
y(n)=s(n)-\alpha s(n-1) .
$$

Dalam hal ini, $y(n)$ adalah signal hasil pre-emphasis, sedangkan $s(n)$ adalah signal sebelum pre-emphasis, simbol $n$ merupakan nomor urut sinyal, $\alpha$ merupakan konstanta filter preemphasis di antara 0,9-1,0 dan $s$ adalah signal. Proses pre-emphasis yang dilakukan seperti pada Gambar 1 menunjukkan bagian (a) merupakan suara masukan sebelum dilakukan preemphasis, sedangkan Gambar 1 bagian (b) adalah hasil output pengolahan signal setelah proses pre-emphasis.

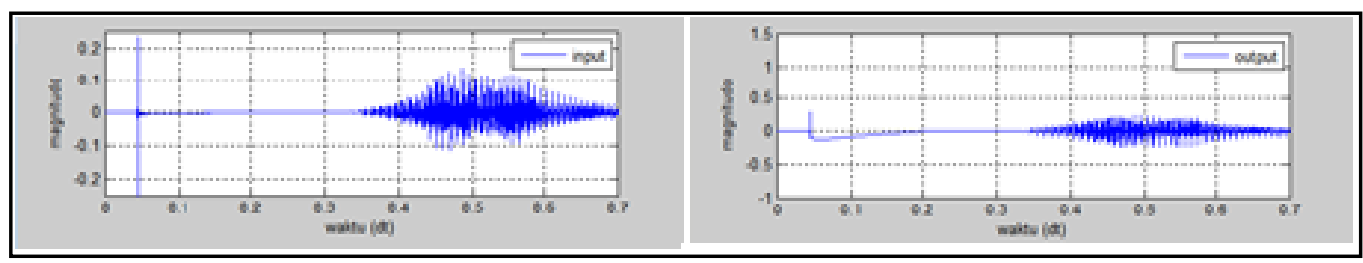

(a)

(b)

Gambar 1. Pre-emphasis (a) sebelum dan (b) sesudah

Pengambilan sinyal ke-n pada pre-emphasis dilakukan sepanjang ucapan satu kata atau dua kata dengan waktu satu sampai tiga detik.

\subsection{Frame blocking}

Sinyal yang telah melalui pre-emphasis selanjutnya dilakukan proses frame blocking yang diblok dalam frame dengan $N$ sampel dan digeser sebesar $M$ sampel sehingga $N=2 M$ 
dengan $M<N$. Gambar 2 menunjukkan ilustrasi frame blocking [1]. Lebar frame dinotasikan dengan $N$, sedangkan lebar pergeseran setiap frame sebagai $M$. Lebar overlap dihitung selisih $N-M$.

Frame blocking menurut Holmes [27] menganalisis sinyal ucapan ke dalam frame yang diwakili oleh fitur vektor tunggal digambarkan dalam spektrum rata-rata interval waktu. Waktu dalam frame diambil rata-rata antara 20-40 milidetik menurut Chamidy [4]. Frame diambil sepanjang mungkin untuk mendapatkan resolusi frekuensi yang baik, sedangkan waktu sependek mungkin dimaksudkan untuk mendapatkan ranah waktu yang terbaik. Perhitungan jumlah frame blocking menggunakan persamaan (2)

$$
f_{l}(n)=y(M l+n) .
$$

Dalam hal ini, $f_{l}(\mathrm{n})$ merupakan hasil frame blocking, simbol $n$ adalah $0,1, \ldots N-1$. Simbol $N$ adalah jumlah sampel, $M$ adalah panjang frame, $l$ adalah $0,1, \ldots L-1$. Simbol $L$ adalah seluruh signal dan $y$ adalah hasil pre-emphasis.

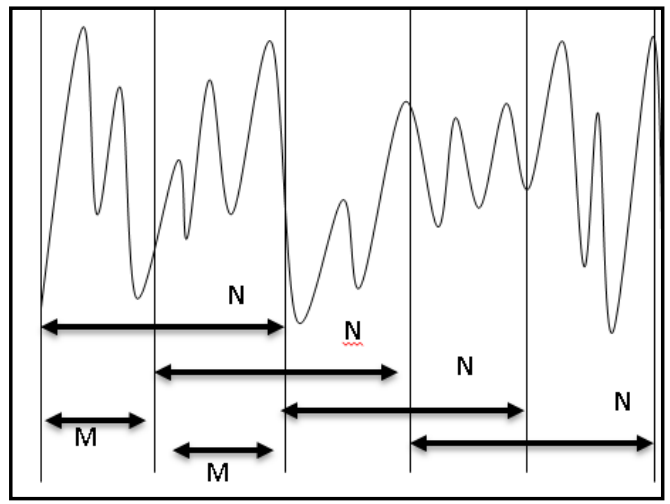

Gambar 2. Ilustrasi Frame blocking [1]

Gambar 2 menunjukkan $M$ adalah frame pertama signal suara dalam formula disimbolkan $f_{l}$ kemudian $M+M=N$.

\subsection{Windowing}

Windowing menurut Proakis dan Manolakis [28] mempunyai fungsi efek menghaluskan pada spektrum setelah melaluai proses frame blocking. Windowing mempunyai tujuan untuk mengurangi efek diskontinue pada ujung-ujung frame yang dihasilkan oleh proses frame blocking. Windowing yang digunakan yaitu Rectangular Window, Hamming Window dan Hanning Window [4]. Dari ketiga fungsi windowing tersebut peneliti menggunakan windowing Hanning dikarenakan lebih halus dibandingkan dengan yang lain [29]. Representasi fungsi windowing menggunakan persamaan (3)

$$
X(n)=f_{l}(n) w(n) .
$$

Dalam hal ini, fungsi $X(n)$ adalah signal hasil windowing, dengan $f_{l}$ adalah hasil frame blocking, dengan $n$ adalah $0,1, \ldots, N-1$. Simbol $N$ adalah jumlah sampel dalam masing-masing 
frame dan $w(n)$ adalah fungsi window. Sedangkan fungsi windowing Hanning menggunakan persamaan (4)

$$
w(n)=0,5\left(1-\cos \left(\frac{2 \pi n}{M-1}\right)\right) .
$$

Dalam hal ini, $w(n)$ adalah fungsi window menggunakan hanning, dengan $n$ adalah $0,1, \ldots, M-1$, $M$ adalah panjang frame. Gambar 3.3 menjelaskan tentang hasil proses windowing menggunakan Hanning window.

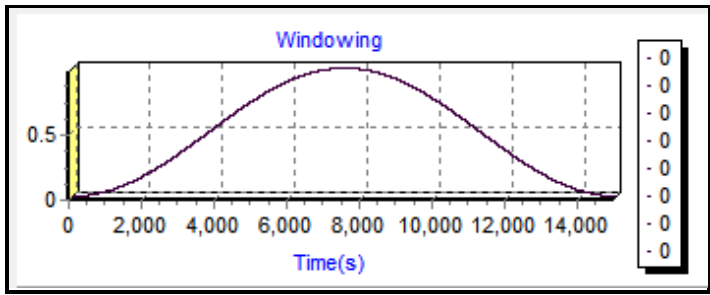

Gambar 3. Ilustrasi windowing [28]

\subsection{Fast Fourier Transform (FFT)}

Fast Fourier Transform adalah pengembangan dari algoritma Discrete Fourier Transform (DFT) yang digunakan untuk mengubah sinyal digital pada ranah waktu ke ranah frekuensi [1]. Sinyal ini pada dasarnya merepresentasikan dekomposisi sinyal dalam hal komponen sinusoidal. Sinusoidal adalah sinusoid dari frekuensi yang sama tetapi amplitudo dan fase yang berbeda. FFT adalah algoritma yang dikembangkan oleh Cooley dan Turki merupakan proses signal dari ranah waktu menjadi ranah frekuensi.

Transformasi fourier menurut Proakis dan Manolakis [28] salah satu dari beberapa alat matematika yang berguna dalam analisis dan desain sistem Linier Time Invarian (LTI) dan deret fourier. FFT adalah salah satu metode algoritma cepat untuk dapat mengimplementasikan Discrete Fourier Transform (DFT). DFT menurut Proakis dan Manolakis [28] alat komputasi yang memainkan peran yang sangat penting dalam banyak aplikasi pemrosesan sinyal digital, seperti analisis frekuensi, estimasi spekturm daya, dan filter linear. Waktu komputasi DFT terlalu lama dan tidak efisien kemudian FFT dapat melakukan efisiensi perhitungan. Seperti yang dikatakan menurut Proakis dan Manolakis [28] bahwa metode FFT digunakan sebagai cara yang efisien untuk dapat menghitung DFT. Discrete Fourier Transform (DFT) menggunakan persamaan (5)

$$
d[m]=\sum_{n=0}^{N-1} X(n) e^{-j \frac{2 \pi}{N} n m} ; m=0,1,2, \ldots, N-1 .
$$

Dalam hal ini, $d[k]$ adalah hasil perhitungan DFT, simbol $X(n)$ adalah hasil windowing. Simbol $N$ adalah bilangan natural, $N$ adalah jumlah sampel yang akan diproses $(N \in \mathrm{N})$. Simbol $k$ adalah variabel frequency discrete bernilai $(m=N / 2, m \in \mathrm{N})$. Fast Fourier Transform mempunyai tujuan mendekomposisi sinyal menjadi sinyal sinusioda yang berupa unit real dan unit imajiner. Fast Fourier Transform menggunakan persamaan (6) 


$$
T(m)=\sum_{n=0}^{N-1} X(n) \cos \left(\frac{2 \pi m n}{N}\right)-\sum_{n=0}^{N-1} X(n) \sin \left(\frac{2 \pi m n}{N}\right)
$$

Dalam hal ini, fungsi $T(m)$ adalah hasil perhitungan Fast Fourier Transform ke-m, simbol $X(n)$ adalah hasil perhitungan windowing ke- $n$. Simbol $n$ adalah nomor urut sinyal. Simbol $m$ adalah indeks dari frekuensi $(1,2, \ldots N)$. Gambar 4 menunjukkan hasil spektrum dengan FFT.

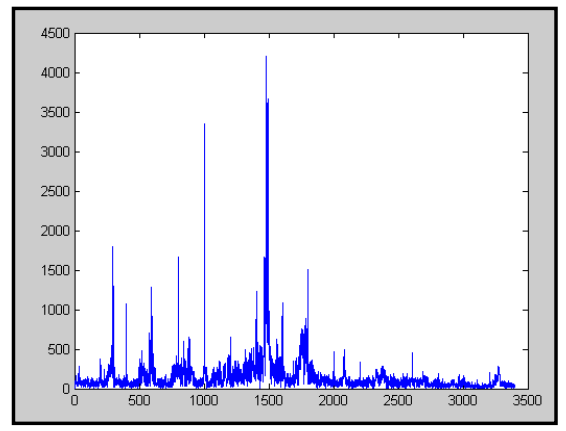

Gambar 4. FFT menghasilkan spektrum [30]

\subsection{Mel Frequency Wrapping (MFW)}

Mel Frequency Wrapping (MFW) merupakan filter berupa filterbank untuk mengetahui ukuran energi dari frequency band tertentu dalam signal suara. MFW menurut Laha [31] mengubah frekuensi ke dalam mel.

Sedangkan MFW menurut Tshilidzi Marwala [32] berisi filterbank, yang diberi jarak pada skala mel. Filterbank memiliki respon frekuensi lewat jalur segitiga yang jarak dan besarnya ditentukan oleh interval frekuensi yang konstan. Proses output yang diperoleh dari filter dikenal dengan spektrum mel. MFW mempunyai tujuan menghasilkan spektrum mel menggunakan persamaan (7)

$$
Y[i]=\sum_{j=1}^{G} T[j] H_{i}[j]
$$

Dalam hal ini, $Y[i]$ adalah hasil perhitungan mel frequency wrapping ke-i dengan $G$ adalah jumlah magnitude spectrum $(G \in \mathrm{N})$, simbol $T[j]$ adalah hasil FFT, $H_{i}[j]$ adalah coefficient filterbank pada frekuensi $j(1 \leq i \leq E)$, dan $E$ adalah jumlah channel dalam filterbank. Pendekatan yang digunakan dalam bentuk mel menggunakan persamaan (8)

$$
\operatorname{mel}(f)=2595 \log _{10}\left(1+\frac{f}{700}\right) \text {. }
$$

Dalam hal ini, mel menggunakan frekuensi dengan skala mel, $f$ sebagai frequency. MFW menghasilkan berupa spektrum mel. Mel frequency scale adalah linear frekuensi skala pada frekuensi di bawah $1.000 \mathrm{~Hz}$ dan merupakan logarithmic skala pada frekuensi di atas $1.000 \mathrm{~Hz}$ (Putra, 2011). Gambar 5 menunjukkan proses spektrum mel. 


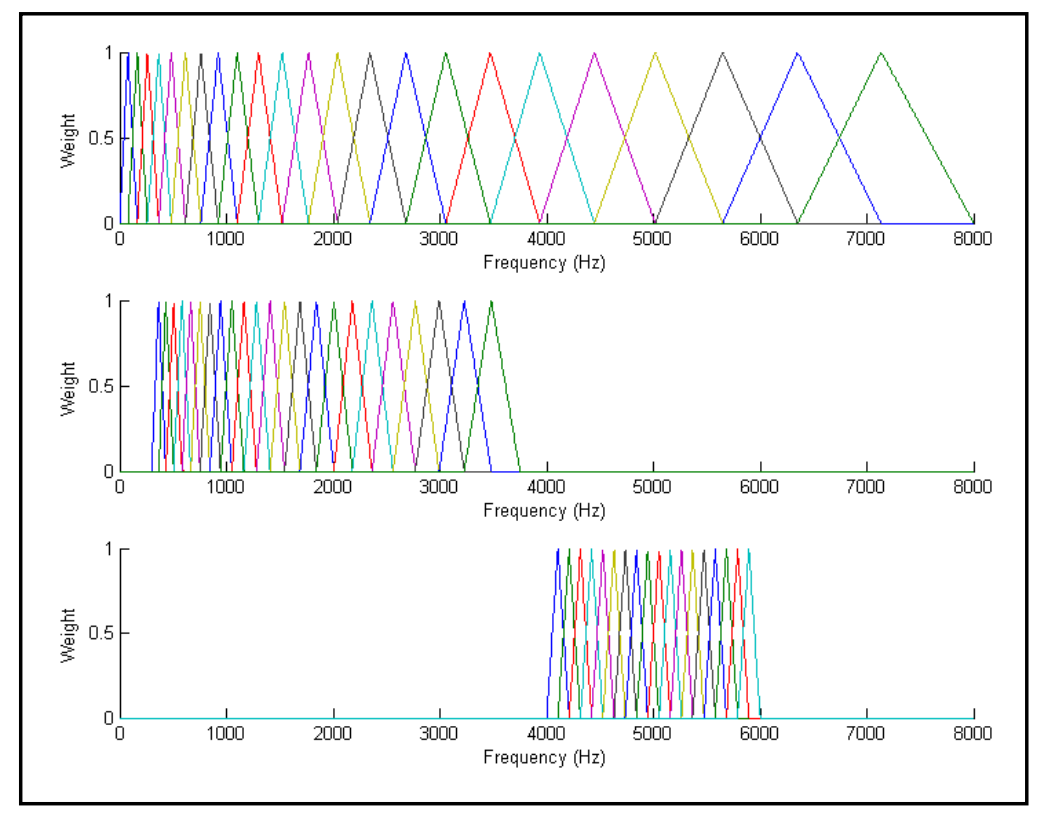

Gambar 5. Spektrum mel

Gambar 5 menunjukkan skala mel dibuat dari filter bank menggunakan jenis filter triangular dalam warna sedangkan weight dalam hal ini $d b$ merupakan amplitude.

\subsection{Discrete Cosine Transform (DCT)}

DCT menurut Smith [34] merupakan kerabat dari transformasi fourier terdekomposisi sinyal ke gelombang cosinus. DCT juga banyak dipakai untuk mengolah image processing misalkan file JPEG. Pada dasarnya konsep dari DCT memiliki kesamaan dengan inverse fourier transform. Namun hasil dari DCT adalah mendekati Principle Component Analysis (PCA). PCA adalah metode static klasik yang digunakan secara luas dalam analisis data dan kompresi. DCT diasumsikan menggantikan inverse fourier transform dalam proses ekstraksi ciri MFCC. Discrete Cosine Transforms (DCT) adalah anggota dari kelas transformasi unit sinusoidal (Britanak dkk., 2007). DCT mempunyai tujuan menghasilkan septrum mel untuk meningkatkan kualitas pengenalan. DCT menggunakan persamaan (9)

$$
C_{r}=\sum_{k=1}^{K}\left(\log _{10} Y[i] \cos \left[r\left(i-\frac{1}{2}\right) \frac{\pi}{K}\right] ; r=1,2, \ldots, K .\right.
$$

Dalam hal ini, $C_{m}$ adalah Coefficient, di mana $Y[i]$ adalah keluaran dari proses filterbank pada indek, $r$ adalah banyaknya coefficient dan $K$ merupakan jumlah coefficient yang diharapkan. Proses DCT menghasilan septrum mel.

\subsection{Cepstral Liftering}

Cepstral coefficient menurut Proakis dan Manolakis [28] merupakan the fourier series coefficients. Septrum didefinisikan oleh Rabiner dan Schafer [36] adalah kebalikannya transformasi fourier. Cepstral liftering meningkatkan akurasi digunakan untuk pattern matching, baik speaker recognition maupun speech recognition. Cepstral coefficient menggunakan persamaan (10) 


$$
w(k)=1+\frac{C}{2} \sin \left(\frac{b \pi}{C}\right) ; b=1,2, \ldots . C
$$

Dalam hal ini, $w(k)$ adalah fungsi window terhadap cepstral features, $C$ adalah cepstral coefficients, simbol $k$ adalah index dari cepstral coefficients. Pengolahan cepstral liftering mempunyai hasil berupa frame dan cepstral coefficients selanjutnya diproses ke pemilihan fitur.

\section{Model Pemilihan Fitur Normalisasi Bobot Dominan (NBD)}

Pemilihan fitur diperlukan dalam hal analisis pengenal suara agar mendapatkan tabel fitur yang tepat. Pemilihan fitur dan referensi yang tepat diperlukan dalam penelitian ini agar pengecekan dan pengujian kesesuaian ucapan menjadi lebih baik dan meningkat.

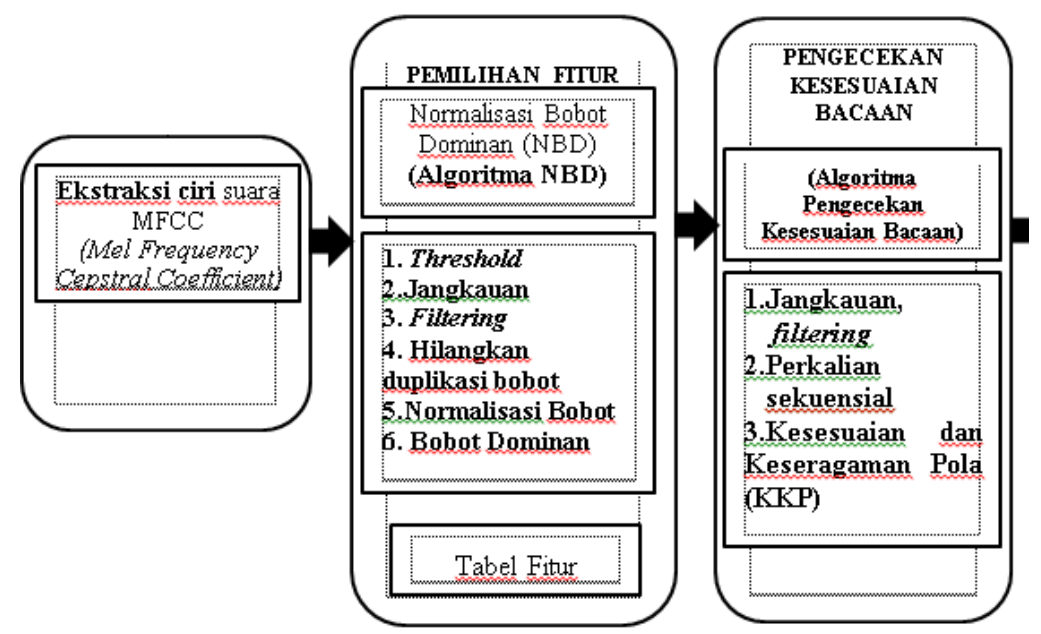

Gambar 6. Pemilihan fitur, pengecekan dan pengujian [37]

Gambar 6 menunjukkan tahap pemilihan fitur, pengecekan dan pengujian kesesuaian ucapan Salam. Pemilihan fitur dilakukan untuk mendapatkan tabel fitur mulai dari ekstraksi ciri MFCC, pengecekan ucapan, sampai pengujian. Pengecekan kesesuaian ucapan Salam digunakan untuk pengujian dengan pemilihan referensi dan fitur yang tepat. Pengecekan terhadap referensi yang tepat dengan cara perulangan ucapan lebih dari satu kali, dipilih yang paling tepat dengan kesamaan jangkauan, filtering, perhitungan perkalian sekuensial dan KKP.

Pengujian terhadap pemilihan fitur yang tepat dilakukan terhadap jumlah cepstral coefficient dan jumlah frame, sedangkan pengujian MFCC tanpa NBD untuk membandingkan akurasi ucapan dengan model NBD. Pengujian yang lain juga dilakukan terhadap hukum ucapan untuk mencari pola kesesuaian ucapan dengan hukum ucapan. 


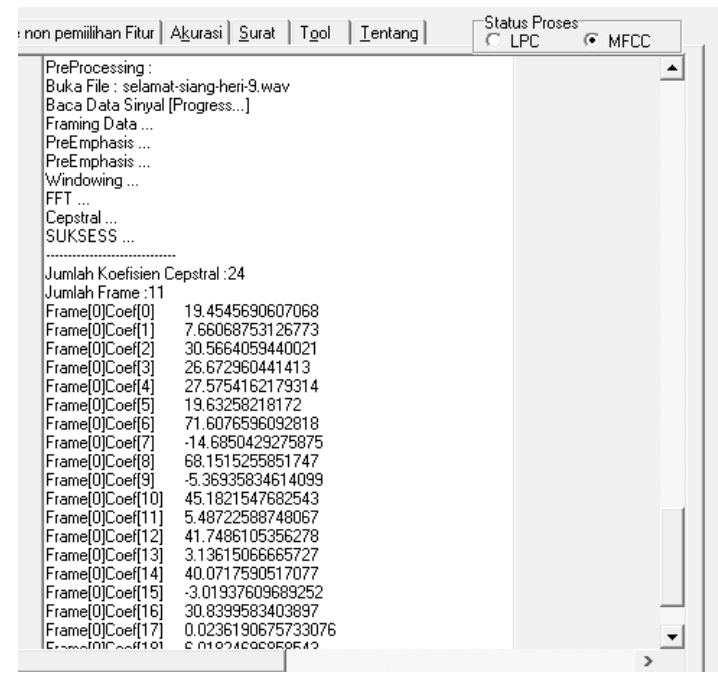

Gambar 7. Output frame dan cepstral coefficient

Gambar 7 menunjukkan hasil MFCC cepstral coefficient sebanyak dua puluh empat dan sebanyak sebelas frame, sedangkan

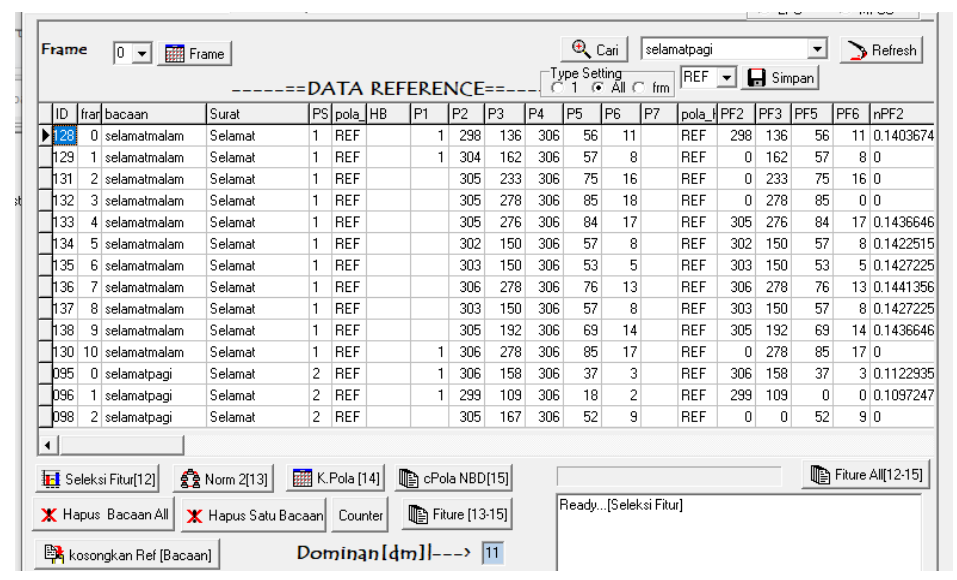

Gambar 8. Hasil MFCC frame dan cepstral coefficients

Gambar 8 menunjukkan hasil MFCC ucapan "iqra" terdiri atas sebelas frame dan dua puluh empat cepstral coefficient.

\subsection{Pemilihan Fitur}

Pemilihan fitur yang diusulkan mempunyai enam tahap, yaitu menentukan threshold yang sama, membuat jangkauan yang sama, melakukan filtering, menghilangkan duplikasi bobot, normalisasi bobot dan bobot dominan [37]. Semua tahap tersebut diterapkan dalam algoritma pemilihan fitur Normalisasi Bobot Dominan (NBD) untuk menghasilkan tabel fitur. 


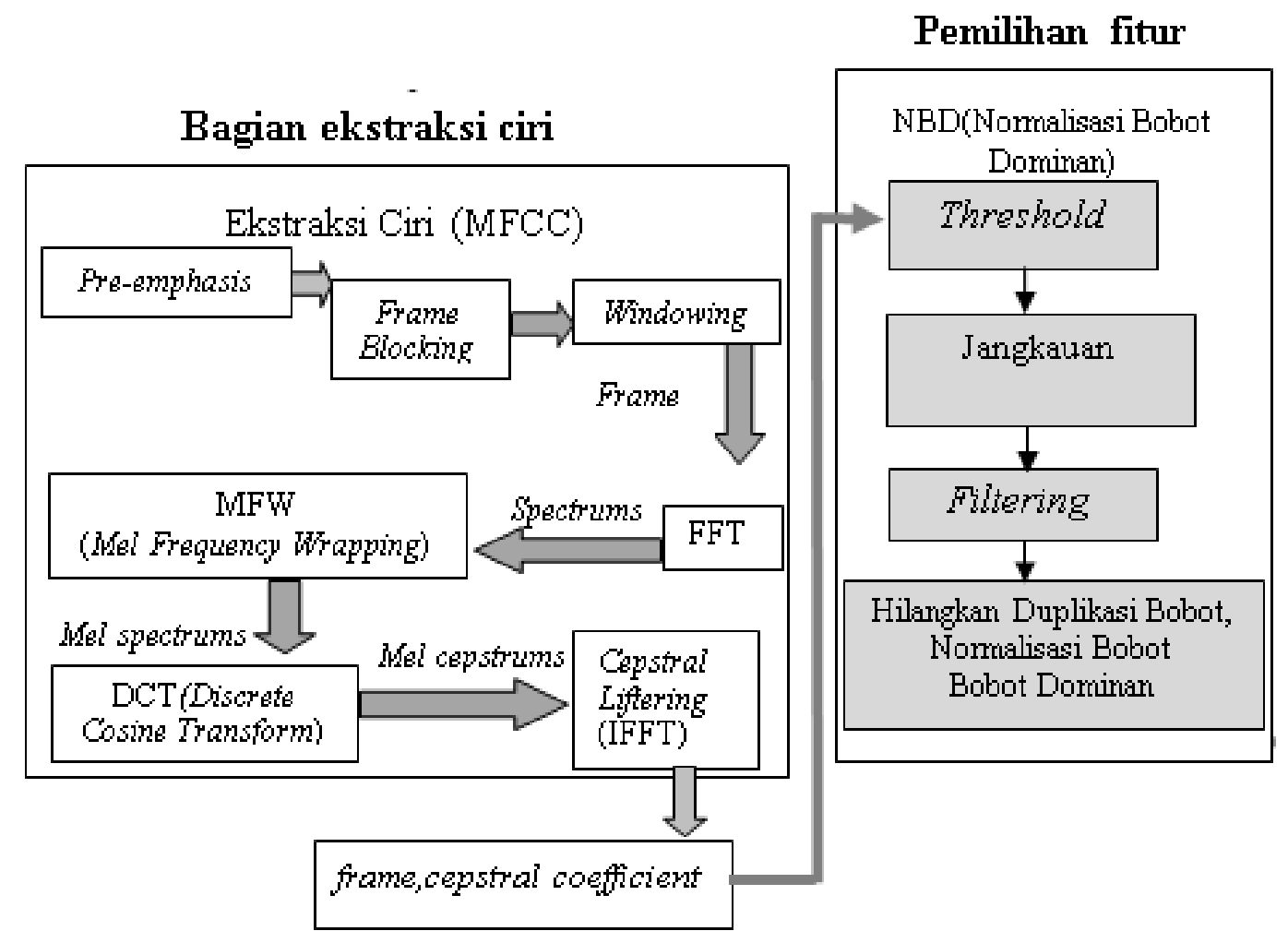

Gambar 9. Ekstraksi ciri dan pemilihan fitur NBD [37]

Gambar 9 menunjukkan penelitian ekstraksi ciri suara menggunakan MFCC yang menghasilkan fitur berupa parameter frame dan cepstral coefficient dan diproses ke pemilihan fitur NBD mulai dari threshold, jangkauan, filtering, menghilangkan duplikasi bobot, normalisasi bobot, hingga bobot dominan. 
Tabel 1. Hasil MFCC ucapan selamat malam

\begin{tabular}{|c|c|c|c|c|}
\hline kodefile & frame_ke & ucapan & koefisien_ke & nilai_koefisien_cepstral \\
\hline 1214269 & 0 & selamatmalam & 0 & 20.38 \\
\hline 1214270 & 0 & selamatmalam & 1 & -3.08 \\
\hline 1214271 & 0 & selamatmalam & 2 & 33.05 \\
\hline 1214272 & 0 & selamatmalam & 3 & 15.86 \\
\hline 1214273 & 0 & selamatmalam & 4 & 36.08 \\
\hline 1214274 & 0 & selamatmalam & 5 & 15.03 \\
\hline 1214275 & 0 & selamatmalam & 6 & 66.50 \\
\hline 1214276 & 0 & selamatmalam & 7 & 9.77 \\
\hline 1214277 & 0 & selamatmalam & 8 & 53.25 \\
\hline 1214278 & 0 & selamatmalam & 9 & 28.77 \\
\hline 1214279 & 0 & selamatmalam & 10 & 47.97 \\
\hline 1214280 & 0 & selamatmalam & 11 & 11.74 \\
\hline 1214281 & 0 & selamatmalam & 12 & 42.65 \\
\hline 1214282 & 0 & selamatmalam & 13 & 1.83 \\
\hline 1214283 & 0 & selamatmalam & 14 & 40.99 \\
\hline 1214284 & 0 & selamatmalam & 15 & -8.42 \\
\hline 1214285 & 0 & selamatmalam & 16 & 38.52 \\
\hline 1214286 & 0 & selamatmalam & 17 & 8.41 \\
\hline 1214287 & 0 & selamatmalam & 18 & 7.38 \\
\hline 1214288 & 0 & selamatmalam & 19 & 0.25 \\
\hline 1214289 & 0 & selamatmalam & 20 & 8.79 \\
\hline 1214290 & 0 & selamatmalam & 21 & 2.98 \\
\hline 1214291 & 0 & selamatmalam & 22 & 3.00 \\
\hline 1214292 & 0 & selamatmalam & 23 & -0.12 \\
\hline 1214293 & 1 & selamatmalam & 0 & 18.23 \\
\hline 1214294 & 1 & selamatmalam & 1 & 0.20 \\
\hline \multirow[t]{3}{*}{1214295} & 1 & selamatmalam & 2 & 29.91 \\
\hline & $\ldots$ & & & \\
\hline & 10 & & & \\
\hline
\end{tabular}

Tabel 1 menujukkan hasil ekstraksi ciri menggunakan MFCC ucapan "selamat malam". Hasil ekstraksi ciri berupa frame yang terdiri atas sebelas frame dan dua puluh empat cepstral coefficient. Proses selenjutnya hasil frame dan cepstral coefficient tersebut dilakukan pemilihan fitur dengan pemilihan fitur frame dengan algoritma pemilihan fitur menggunakan Normalisasi Bobot Dominan.

Gambar 10 menunjukkan algoritma NBD yang dimulai dari langkah pertama dan kedua pengambilan suara ucapan, langkah ketiga melakukan proses threshold. Kemudian, pada langkah keempat dan seterusnya dibuat jangkauan, filtering, menghilangkan duplikasi bobot, dilakukan normalisasi bobot dan bobot dominan. 
0 . Mulai

1. Ambil suara ucapan

2. Fungsi MFCC dengan frame $=f$, cepstral coefficient $(\boldsymbol{c})=\boldsymbol{w}(\boldsymbol{k})$

3. Menentukan threshold 1 sampai threshold $6\left(b_{1}-b_{6}\right)$
a. Buat $\mathbf{b}_{1}=\min (\mathrm{w}(\mathrm{k}))$,
b. buat $\mathbf{b}_{2}=\frac{\min (w(k))+\left(\frac{\min (w(k))+\max (w(k))}{2}\right)}{2}$
c. buat $\mathbf{b}_{3}=$ rata $-\operatorname{rata}(w(k))$,
d. buat $\mathbf{b}_{\mathbf{4}}=\frac{\min (w(k))+\max (w(k))}{2}$
e. buat $\mathbf{b}_{5}=\frac{\left(\frac{\min (w(k))+\max (w(k))}{2}\right)+\max (w(k))}{2}$,
f. $\quad$ buat $\mathbf{b}_{6}=\max (w(k))$.

4. Membuat jangkauan

Jangkauan dengan cek kondisi di setiap frame dengan cepstral coefficient $(c)=w(k)$ Bobot=1

a. Rule 1 adalah if $\left(\boldsymbol{b}_{1}\right) \min =w(k)$ then $\boldsymbol{p}_{\boldsymbol{i 1}}=$ bobot elseif bobot $=0$

b. Rule 2 adalah if $\left(\boldsymbol{b}_{1}\right) \geq=w(k)$ and $\left(w(k)<\boldsymbol{b}_{2}\right)$ then $\boldsymbol{p}_{\mathrm{i} 2}=$ bobot elseif bobot $=0$

c. Rule 3 adalah if $\left(\boldsymbol{b}_{2}\right) \geq=w(k)$ and $\left(w(k)<\boldsymbol{b}_{3}\right)$ then $\boldsymbol{p}_{i 3}=$ bobot elseif bobot $=0$

d Rule 4 adalah if $\left(\boldsymbol{b}_{3}\right) \geq=w(k)$ and $\left(w(k)<\boldsymbol{b}_{4}\right)$ then $\boldsymbol{p}_{\text {i4 }}=$ bobot elseif bobot $=0$

e. Rule 5 adalah if $\left(\boldsymbol{b}_{4}\right) \geq=w(k)$ and $\left(w(k)<\boldsymbol{b}_{5}\right)$ then $\boldsymbol{p}_{i 5}=$ bobot elseif bobot $=0$

f.Rule 6 dalah if $\left(b_{5}\right) \geq=w(k)$ and $\left(w(k)<b_{6}\right)$ then $p_{i 6}=$ bobot elseif bobot $=0$

$g$ Rule 7 adalah if $\left(\boldsymbol{b}_{6}\right) \max =w(k)$ then $\boldsymbol{p}_{i 7}=$ bobot elseif bobot $=0$

\section{Filtering}

Hasil filtering berupa $\boldsymbol{p}_{i 1}$ sampai $\boldsymbol{p}_{i 7}$

Hitung jumlah $\boldsymbol{p}_{i 1}$ sampai $\boldsymbol{p}_{i 7}$ dengan $G_{j}=\sum_{i=0}^{F} p_{i j}$

Hitung Jumlah seluruh pola dengan $U=\sum_{j=0}^{a} G_{j}$

6. Menghilangkan duplikasi bobot

Tetapkan bahwa $Q_{i j=} p_{i j}$ dan mencari kesamaan menghilangkan duplikasi.

if $Q_{i 0}=p_{i 1}$ then $Q_{i j}=0$, if $Q_{i 1}=p_{i 2}$ then $Q_{j j}=0$, if $Q_{i 2}=p_{i 3}$ then $Q_{i j}=0$

if $Q_{i 0}=p_{i 2}$ then $Q_{i j}=0$, if $Q_{i 1}=p_{i 3}$ then $Q_{j j}=0$, if $Q_{i 2}=p_{i 4}$ then $Q_{i j}=0$

if $Q_{i 0}=p_{i 10}$ then $Q_{i j}=0$, if $Q_{i 1}=p_{i 10}$ then $Q_{i j}=0$, if $Q_{i 2}=p_{i 10}$ then $Q_{i j}=0$

g. Perhitungan Jumlah dengan $Z_{j}=\sum_{i=0}^{F} Q_{i j}$

\section{Normalisasi Bobot}

Perhitungan Normalisasi Bobot dengan $S_{j}=\sum_{i=0}^{F} \frac{Q_{i j}}{Z_{j}}$

h. Bobot dominan

Urutkan nilai terbesar $S_{j}$ di tabel fitur $\left(\mathrm{npf}_{2}, \mathrm{npf}_{3}, \mathrm{npf}_{5}, \mathrm{npf}_{6}\right)$ menjadi variabel $\boldsymbol{B}_{\boldsymbol{j}}$

i. Simpan tabel fitur perhitungan jumlah bobot $=Z$,

Normalisasi bobot $=S$, keseluruhan pola $=U$

10. selesai

Gambar 10. Algoritma pemilihan fitur dengan NBD [37] 


\subsection{Pengumpulan Data}

Pengambilan sampling suara dilakukan sebanyak 296 suara reakman dan diujikan terahdap 296 suara rekaman. Penggunakan cepstral coefficient yang digunakan mulai dari 0 sampai dengan 23 sebanyak 24 cepstral coefficient dan 0 sampai 10 frame. Frekuensi yang digunakan menggunakan 44,100 kHz stereo 16 bit dengan merekam suara laki-laki dan suara perempuan.

Tabel 2. Data rekaman suara Training

\begin{tabular}{llll}
\hline NO & Jenis Kelamin & Ucapan & $\begin{array}{l}\text { Jumlah } \\
\text { Sampling }\end{array}$ \\
\hline 1 & Laki-Laki & Selamat Pagi & 37 \\
\hline 2 & Laki-Laki & Selamat Siang & 37 \\
\hline 3 & Laki-Laki & Selamat Sore & 37 \\
\hline 4 & Laki-Laki & Selamat Malaam & 37 \\
\hline 1 & Perempuan & Selamat Pagi & 37 \\
\hline 2 & Perempuan & Selamat Siang & 37 \\
\hline 3 & Perempuan & Selamat Sore & 37 \\
\hline 4 & Perempuan & Selamat Malaam & 37 \\
\hline & & & 296 \\
\hline
\end{tabular}

Tabel 3. Data rekaman Uji

\begin{tabular}{llll}
\hline NO & Jenis Kelamin & Ucapan & $\begin{array}{l}\text { Jumlah } \\
\text { Sampling }\end{array}$ \\
\hline 1 & Laki-Laki & Selamat Pagi & 37 \\
\hline 2 & Laki-Laki & Selamat Siang & 37 \\
\hline 3 & Laki-Laki & Selamat Sore & 37 \\
\hline 4 & Laki-Laki & Selamat Malaam & 37 \\
\hline 1 & Perempuan & Selamat Pagi & 37 \\
\hline 2 & Perempuan & Selamat Siang & 37 \\
\hline 3 & Perempuan & Selamat Sore & 37 \\
\hline 4 & Perempuan & Selamat Malaam & 37 \\
\hline & & & 296 \\
\hline
\end{tabular}

Tabel 2 dan tabel 3 pengambilan sampling suara untuk masing-masing suara ucapan bacaan 37 sampling baik laki-laki maupun perempuan. Total pengambilan suara sebanyak 296 suara.

\section{Hasil dan Pembahasan (Heading 1)}

Pengecekan kesesuaian ucapan Salam dilakukan terhadap tabel fitur dengan perhitungan KKP. Perhitungan hasil kesesuaian ucapan tersebut diharapkan mendekati dengan hasil yang ada pada tabel fitur sehingga persentase kesesuaian ucapan menjadi meningkat. Pengecekan terhadap tabel fitur yang ada threshold dengan kesamaan jangkauan dan filtering, perhitungan sekuensial dan perhitungan KKP menggunakan persamaan seperti dalam algoritma. Pengecekan ucapan tersebut dilakukan terhadap pemilihan referensi yang tepat dan pemilihan fitur yang tepat. 


\section{Algoritma Pengecekan Kesesuaian Ucapan Salam}

0. Mulai

1. Ambil suara ucapan Salam

2. Fungsi MFCCdengan frame $=f$, cepstral coefficient $(c)=w(k)$

3. Pengecekan jangkauan dan filtering setiap frame $i=0,1,2, \ldots, F$

a. Ambil tabel fitur yang ada threshold $\left(\boldsymbol{b}_{1}-\boldsymbol{b}_{6}\right)$

b. Lakukan pengecekan jangkauan atau range dengan $w(c)$ jika terpenuhi $p_{i j}$ diberi bobot $=1$

c. rule 1 dengan if $\left(\boldsymbol{b}_{1} \min =\boldsymbol{w}(\boldsymbol{k})\right)$ then $\boldsymbol{R}_{\boldsymbol{i 1}}=$ bobot elseif bobot $=0$

d. rule 2 dengan if $\left(\boldsymbol{b}_{1}>=\boldsymbol{w}(\boldsymbol{k})\right)$ and $(\boldsymbol{w}(\boldsymbol{k})<\mathrm{b} 2)$ then $\boldsymbol{R}_{\boldsymbol{i} 2}=$ bobot elseif bobot $=0$

e. rule dengan if $\left(\boldsymbol{b}_{\mathbf{2}}>=\boldsymbol{w}(\boldsymbol{k})\right)$ and $(\boldsymbol{w}(\boldsymbol{k})<\mathrm{b} 3)$ then $\boldsymbol{R}_{\mathbf{i}}=$ bobot elseif bobot $=0$

f. rule 4 dengan if $\left(\boldsymbol{b}_{3}>=\boldsymbol{w}(\boldsymbol{k})\right)$ and $(\boldsymbol{w}(\boldsymbol{k})<\mathrm{b} 4)$ then $\boldsymbol{R}_{\boldsymbol{i}}=$ bobot elseif bobot $=0$

g. rules dengan if $\left(\boldsymbol{b}_{4}>=\boldsymbol{w}(\boldsymbol{k})\right)$ and $(\boldsymbol{w}(\boldsymbol{k})<b 5)$ then $\boldsymbol{R}_{i 5}=$ bobot elseif bobot $=0$

h. rule 6 dengan if $\left(\boldsymbol{b}_{5}>=\boldsymbol{w}(\boldsymbol{k})\right)$ and $(\boldsymbol{w}(\boldsymbol{k})<b 6)$ then $\boldsymbol{R}_{\boldsymbol{i}}=$ bobot elseif bobot $=0$

i. rulez dengan if $\left(\boldsymbol{b}_{\boldsymbol{6}}=\boldsymbol{w}(\boldsymbol{k})\right)$ then $\boldsymbol{R}_{\boldsymbol{i}}=$ bobot elseif bobot $=0$

j. Filtering simpan filtering yang terakumulasi dengan $R_{i j}, j=2,3,5$ dan 6 .

4. Perkalian sekuensial dengan tabel fitur

Hitung perkalian sekunensial $P_{i j}$, dengan $j=2,3,5$ dan 6

$$
P_{j}=\sum_{i=0}^{F}\left(R_{i j} B_{i j} Z_{i j}^{2}\right)
$$

\section{Hitung dengan formula KKP P2,P3, P5 dan P6}

$$
K_{j}=\frac{\overline{P_{j}} \bar{U}}{\overline{Z_{j}^{2}}} \quad K=\frac{\left(\overline{P_{2}}+\overline{P_{3}}+\overline{P_{5}}+\overline{P_{6}}\right) \bar{U}}{\overline{Z_{2}^{2}}+\overline{Z_{3}^{2}}+\overline{Z_{5}^{2}}+\overline{Z_{6}^{2}}}
$$

\section{6. selesai}

Gambar 11. Algoritma pengecekan kesesuaian ucapan salam

Gambar 11 menunjukkan algoritma pengecekan kesesuaian ucapan dengan tabel 2 hasil fitur dimulai dari suara ucapan salam, kemudian ekstraksi ciri menggunakan MFCC menghasilkan komponen frame dan cepstral coefficient di langkah kedua. Langkah ketiga, algoritma pengecekan ucapan pembaca dimulai dengan ekstraksi ciri MFCC yang menghasilkan komponen frame dan cepstral coefficient. Berikut hasil pengujian dapat dilihat pada Tabel 2.

Tabel 4. Hasil Ucapan Selamat

\begin{tabular}{rrrrrrrrrrrrrrr}
\hline & & & \multicolumn{10}{c}{ Frame } \\
\cline { 6 - 14 } No & \multirow{2}{*}{ UCAPAN } & Sampling & MFCC & $\mathbf{0}$ & $\mathbf{1}$ & $\mathbf{2}$ & $\mathbf{3}$ & $\mathbf{4}$ & $\mathbf{5}$ & $\mathbf{6}$ & $\mathbf{7}$ & $\mathbf{8}$ & $\mathbf{9}$ & $\mathbf{1 0}$ \\
\hline 1 & Selamat Pagi & 74 & 60 & 10 & 10 & 20 & 40 & 30 & 40 & 30 & 40 & 50 & 60 & 40 \\
\hline 2 & Selamat Siang & 74 & 90 & 30 & 30 & 50 & 80 & 50 & 60 & 50 & 40 & 70 & 90 & 70 \\
\hline 3 & Selamat Sore & 74 & 100 & 50 & 50 & 70 & 60 & 80 & 50 & 60 & 50 & 80 & 100 & 90 \\
\hline 4 & Selamat Malam & 74 & 90 & 50 & 50 & 60 & 50 & 60 & 70 & 60 & 50 & 80 & 90 & 90 \\
\hline & 296 & 85 & 35 & 35 & 50 & 58 & 55 & 55 & 50 & 45 & 70 & 85 & 73 \\
\hline
\end{tabular}


Berdasarkan tabel 2 dengan pemilihan fitur frame yang terbaik pada frame ke- 9 dengan nilai rata-rata $85 \%$ lebih baik dibandingan dengan frame yang lain.

\section{Kesimpulan dan Saran}

Penelitian ini untuk menggunakan MFCC dan pemilihan fitur frame yang tepat untuk ucapakan selamat pagi, selamat siang, selamat sore dan selamat malam yang menghasilkan frame dan cepstral coefficient. Penggunakan cepstral coefficient yang digunakan mulai dari 0 sampai dengan 23 sebanyak 24 cepstral coefficient. Pengambilan sampling suara sebanyak 296 suara rekaman diujikan terhadap 296 suara rekaman. Frekuensi yang digunakan menggunakan 44,100 kHz stereo 16 bit. Hasil akurasi didapat bahwa metode MFCC dengan pemilihan fitur frame yang ke-9 mempunyai tingkat akurasi yang lebih tinggi sebesar $85 \%$ dibandingkan dengan frame yang lain

\section{Daftar Pustaka}

[1] Abriyono and A. Harjoko, "Pengenalan Ucapan Suku Kata Bahasa Lisan Menggunakan Ciri LPC, MFCC, dan JST," Indones. J. Comput. Cybern. Syst., vol. 6, no. 2, pp. 23-34, 2012.

[2] F. Syafria, A. Buono, and B. I. B. P. Silalahi, "Pengenalan Suara Paru - Paru dengan MFCC sebagai Ekstraksi Ciri dan Backpropagation sebagai Classifier," vol. 3, 2014.

[3] H. S. Manunggal, "Perancangan dan Pembuatan Perangkat Lunak Pengenalan Suara Pembicara Dengan Menggunakan Analisa MFCC Feature Extraction.," Tugas Akhir Sarj. pada Jur. Tek. Inform. Fak. Teknol. Ind. Univ. Kristen Petra Surabaya, 2005.

[4] T. Chamidy, "Metode Mel Frequency Cepstral Coeffisients (MFCC) Pada klasifikasi Hidden Markov Model (HMM) Untuk Kata Arabic pada Penutur Indonesia," Matics, vol. 8, no. 1, pp. 36-39, 2016.

[5] Irmawan, H. Hikmarika, D. W. Sari, and M. C. Tammimi, "Pengenalan Kata dengan Metode Linear Predictive Coding dan Jaringan Syaraf Tiruan Pada Mobile Robot," no. December, 2014.

[6] H. S. Thiang, "Sistem Pengenalan Kata dengan Menggunakan Linear Predictive Coding dan Nearest Neighbor Classifier," Univ. Kristen Petra, vol. 5, no. September, pp. 1924, 2005.

[7] A. M. Aibinu, M. J. E. Salami, A. R. Najeeb, J. F. Azeez, and S. M. A. K. Rajin, "Evaluating the effect of voice activity detection in isolated Yoruba word recognition system," 2011 4th Int. Conf. Mechatronics Integr. Eng. Ind. Soc. Dev. ICOM'11 - Conf. Proc., no. May, pp. 17-19, 2011, doi: 10.1109/ICOM.2011.5937134.

[8] S. Hidayat, R. Hidayat, and T. B. Adji, "Sistem Pengenal Tutur Bahasa Indonesia Berbasis Suku Kata Menggunakan MFCC, Wavelet Dan HMM," Conf. Inf. Technol. Electr. Eng., no. September, pp. 246-251, 2015.

[9] S. M. Widodo, E. Siswanto, and O. Sudjana, "Penerapan Metode Mel Frequency Ceptral Coefficient dan Learning Vector Quantization untuk Text-Dependent Speaker Identification," vol. 11, no. 1, pp. 15-20, 2016. 
[10] Suyanto and S. Hartati, "Design of Indonesian LVCSR using Combined Phoneme The Approaches of LVCSR,” Icts, pp. 191-196, 2013, doi: 10.12962/p9772338185001.a33a33.

[11] S. Suyanto and A. E. Putra, "Automatic Segmentation of Indonesian Speech into Syllables using Fuzzy Smoothed Energy Contour with Local Normalization, Splitting, and Assimilation," J. ICT Res. Appl., vol. 8, no. 2, pp. 97-112, 2014, doi: 10.5614/itbj.ict.res.appl.2014.8.2.2.

[12] R. Cahyarini, U. L. Yuhana, and A. Munif, "Rancang Bangun Modul Pengenalan Suara Menggunakan Teknologi Kinect,”J. Tek. Pomits, vol. 2, no. 1, pp. 1-5, 2013.

[13] M. K. A. S. . dan S. Hertiana Bethaningtyas, "Pengenalan Huruf Hijayyah Berbasis Pengolahan Sinyal Suara dengan Metode MFCC," Momentum, Vol.13, No. 2 Oktober 2017 ISSN 2406-9329 Hal 49-52 Fak. Tek. WAHID HASYIM SEMARANGe-, vol. 13, no. 2, pp. 49$52,2017$.

[14] Heriyanto, "Analisa Deteksi Huruf Hijaiyah Melalui Voice Recognition Menggunakan Kombinasi Energy," Telematika, vol. 12, no. 01, pp. 11-22, 2015.

[15] M. Subali, M. Andriansyah, and C. Sinambela, "ANALISIS FREKUENSI DASAR DAN FREKUENSI FORMANT DARI FONEM HURUH HIJAIYAH UNTUK PENGUCAPAN MAKHRAJ DENGAN METODE DTW," Pros. PESAT (Psikologi, Ekon. Sastra, Arsit. \&Teknik Sipil) Vol. 6, Oktober 2015 ISSN 1858-2559 Univ. Gunadarma - Depok - 20-21 Oktober 2015 Hal S-60-72, vol. 6, pp. S60-72, 2015.

[16] C. G. K. Leon, "Robust computer voice recognition using improved MFCC algorithm," Proc. - 2009 Int. Conf. New Trends Inf. Serv. Sci. NISS 2009, pp. 835-840, 2009, doi: 10.1109/NISS.2009.12.

[17] L. Muda, M. Begam, and I. Elamvazuthi, "Voice Recognition Algorithms using Mel Frequency Cepstral Coefficient (MFCC) and Dynamic Time Warping (DTW) Techniques," vol. 2, no. 3, pp. 138-143, 2010, [Online]. Available: http://arxiv.org/abs/1003.4083.

[18] M. W. . Sanjaya and Z. Salleh, "Implementasi Pengenalan Pola Suara Menggunakan Mel-Frequency Cepstrum Coefficients (Mfcc) Dan Adaptive Neuro-Fuzzy Inferense System (Anfis) Sebagai Kontrol Lampu Otomatis," Al-HAZEN J. Phys., vol. 1, no. 1, pp. 1-19, 2014.

[19] Y. Miftahuddin and M. R. Hakim, "COEFFICIENT DAN DYNAMIC TIME WARPING UNTUK PENGENALAN NADA PADA ALAT MUSIK BELLYRA,” pp. 120127, 2017.

[20] A. R. Darma Putra, "Verifikasi Biometrika Suara Menggunakan Metode MFCC dan DTW," LONTAR Komput. Biometrika, Univ. Udayana ISSN2088-1541, vol. 2, no. 1, pp. 821, 2011.

[21] D. Novianto and R. V. Yuliantari, "Pengenalan Isyarat Tutur Vokal Bahasa Indonesia Menggunakan Metode Dynamic Time Wraping ( Dtw ) Berbasis Fungsi Jarak,” no. 1, pp. 1-4, 2017.

[22] S. Martyna and S. Sudaryanto, "Penerapan Metode Particle Swarm Optimization pada Artificial Neural Network Backpropagation untuk Peramalan Penjualan Furniture pada CV. Octo Agung," pp. 1-9, 2011. 
[23] A. M. Aibinu, M. J. E. Salami, A. R. Najeeb, J. F. Azeez, and S. M. A. K. Rajin, "Evaluating the effect of voice activity detection in isolated Yoruba word recognition system," 2011 4th Int. Conf. Mechatronics Integr. Eng. Ind. Soc. Dev. ICOM'11 - Conf. Proc., no. May, pp. 17-19, 2011, doi: 10.1109/ICOM.2011.5937134.

[24] S. B. Davis and P. Mermelstein, "Comparison of Parametric Representations for Monosyllabic Word Recognition in Continuously Spoken Sentences," IEEE Trans. Acoust., vol. 28, no. 4, pp. 357-366, 1980, doi: 10.1109/TASSP.1980.1163420.

[25] D. J. . Chitode, "01.Communication Theory.” 2010.

[26] R. T. M. (Sim) narasimha Tokunbo Ogunfunmi, Speech and Audio Processing and Recognition, no. part 1. springer, 2015.

[27] J. H. and W. Holmes, Speech Synthesis and Recognition, Second Edition. 2003.

[28] J. G. Proakis and D. G. Manolakis, Digital Signal Processing: Principles, algorithms, and applications. 1996.

[29] A. E. Putra, "Frekuensi Cuplik pada FFT," Tan Li, Process. Digit. Signal, vol. 1, 2008.

[30] A. A. Kumar, Digital signal processing, vol. 23, no. 4. Prentice-Hall of India Pvt.Ltd, 2013.

[31] D. Laha, Handbook of Computational Intelligence in Manufacturing and Production Manajemen. 2007.

[32] Tshilidzi Marwala, Condition Monitoring Using Computational Intelligence Methods. 2012.

[33] T. Hassan, A. Wassim, and M. Bassem, "Analysis and Implementation of an Automated Delimiter of "Quranic " Verses in Audio Files using Speech Recognition Techniques," Robust Speech Recognit. Underst., no. June, pp. 352-362, 2007, doi: $10.5772 / 4759$.

[34] S. W. Smith, Digital signal processing, vol. 17, no. 2. 2000.

[35] K. R. R. Vladimir Britanak, Patrick C.Yip, Discrete Cosine and Sine Transform. 2007.

[36] L. R. Rabiner and R. W. Schafer, Introduction to digital speech processing, vol. 1, no. 1. 2007.

[37] H.- Heriyanto, S. Hartati, and A. E. Putra, "Evaluation of Suitability of Voice Reading of Al-Qur'an Verses Based on Tajwid Using Mel Frequency Cepstral Coefficients (MFCC) and Normalization of Dominant Weight (NDW)," Adv. Image Video Process., vol. 6, no. 2, 2018, doi: 10.14738/aivp.62.4268. 